\section{Method for Rapid Restriction Analysis of YAC Clones}

BioTechniques 21:404-406 (September 1996)

The development of the yeast artificial chromosome (YACs) technology (3) has provided, by virtue of its capacity to carry large fragments of genomic DNA, the possibility of linking the genetic map and the physical map of an organism. This requires the alignment of overlapping YAC clones into contigs for which a number of strategies have been described as follows: the use of sequence tagged sites (STSs) (8), YAC fingerprinting using dispersed repeat sequences (2) and the use of rare cutter enzyme mapping (9).

A method for YAC alignment by partial restriction analysis has recently been described (10). However, this method is not very reproducible in our hands, since no or very little digestion was observed with 100 units of enzyme and an incubation of one hour at the appropriate temperature. To overcome this problem, a series of modifications of this latter method (essentially by replacing bovine serum albumin with casein and decreasing the amount of restriction enzyme), enabled us to obtain a highly flexible protocol for the rapid restriction mapping of YAC clones.

Our method is based on partial digestion of YACs with rare cutter enzymes and pulsed-field gel electrophoresis (4). Agarose blocks, from individual YAC clones, were prepared (1) and washed overnight in $1 \times$ TE (10 mM Tris-HCl, 1 mM EDTA, pH 8.0) at $4^{\circ} \mathrm{C}$ to remove the excess EDTA. Partial digestion of YACs by time limitation was performed in a total volume of $200 \mu \mathrm{L}$, which was obtained by making the following mixture: $20 \mu \mathrm{L}$ of $10 \times$ casein mixture [i.e., $1 \mathrm{mg} / \mathrm{mL}$ casein (6), $20 \mu \mathrm{M}$ dithiothreitol (DTT) and $40 \mu \mathrm{M}$ spermidine]; $20 \mu \mathrm{L}$ of the appropriate $10 \times$ concentrated reaction buffer (supplied with the enzyme), $80 \mu \mathrm{L} \mathrm{ddH_{2 }} \mathrm{O}$ and $80 \mu \mathrm{L}$ of YAC containing agarose block. This mixture was cooled on ice for $30 \mathrm{~min}$, and the appropriate amount of enzyme was subsequently added. The mixture was again incubated on ice for $30 \mathrm{~min}$ to allow diffusion of the enzyme in the agarose block. Following these incubation steps, the mixture was transferred to a water bath to bring it to the temperature recommended by the manufacturer of the enzyme. Digestion was terminated through the addition of $1 \mathrm{~mL}$ of $0.5 \mathrm{M}$ EDTA, pH 8.0. Fragments were separated on a $1 \%$ pulsedfield gel, blotted onto Hybond ${ }^{\mathrm{TM}}-\mathrm{N}$ membranes (Amersham, Arlington Heights, IL, USA), hybridized, washed and autoradiographed as previously described (5).

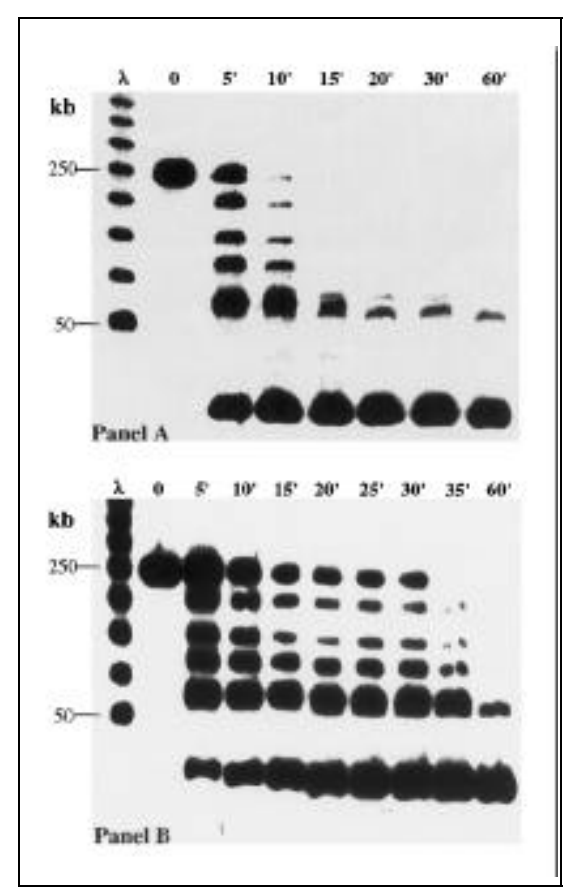

Figure 1. Partial digestion of a 250-kb sugar beet YAC clone with $M l u I$ by time limitation. The above figures illustrate partial digestion of YAC DNA embedded in agarose blocks, digested for 5 to 60 min with $M l u \mathrm{I}$ at $37^{\circ} \mathrm{C}$. Panel A shows the partial digestion of YAC DNA contained in agarose blocks, with $10 \mathrm{U}$ of $M l u \mathrm{I}$ per sample. Panel B shows the partial digestion of the same YAC clone embedded in agarose with $5 \mathrm{U}$ of MluI per sample. Pulsed-field gel electrophoresis was performed with a switch time interval between 5 and $30 \mathrm{~s}, 6.0 \mathrm{~V} / \mathrm{cm}$ for $20 \mathrm{~h}$, blotted and hybridized at $65^{\circ} \mathrm{C}$ for $16 \mathrm{~h}$ with a [ $\left.{ }^{32} \mathrm{P}\right] \mathrm{dCTP}-\mathrm{la}-$ beled left-end (ARS1/TRP1) probe (7). After hybridization, the filters were washed two times for 15 min each with increasing stringency washes as follows: $2 \times$ SSC, $0.1 \%$ SDS; $1 \times$ SSC, $0.1 \%$ SDS; and $0.5 \times$ SSC, $0.1 \%$ SDS. After the last wash, filters were wrapped in plastic wrap and autoradiographed for $4 \mathrm{~h}$ at $-80^{\circ} \mathrm{C}$. The lane marked with $\lambda$ represents a concatenated $\lambda$ ladder (Boehringer Mannheim, Mannheim, Germany) serving as a size marker. Incubation times (in $\mathrm{min}$ ) are indicated above each lane.
A 2.7-kb pBR322 PvuII/BamHI fragment was used to detect the left arm (ARS1/TRP1), and a 1.7-kb PvuII/ BamHI fragment was used to detect the right arm (URA3). Figure 1 shows the results from these experiments by using different amounts of $M l u \mathrm{I}$ on a $250-\mathrm{kb}$ sugar beet YAC clone. This figure shows that, depending on the amount of enzyme used, partial digestion is accomplished between 5 and $10 \mathrm{~min}$ when $10 \mathrm{U}$ of enzyme are used (Panel A), or between 5 and 30 min when $5 \mathrm{U}$ of enzyme are used (Panel B). These results also show that, by using $5 \mathrm{U}$ of enzyme together with the casein containing reaction mixture, the incubation time is less critical, resulting in a flexible method, which is highly reproducible. Repeating this experiment in the absence of the casein mixture resulted in no or very little digestion of the agarose-embedded YAC DNA after $1 \mathrm{~h}$ of incubation at the appropriate temperature.

Further investigations showed that other enzymes like NotI, NarI and EagI $\left(37^{\circ} \mathrm{C}\right.$ digestion) had the same range of partial digestion when $5 \mathrm{U}$ of these enzymes were used, while enzymes like SfiI and $\mathrm{Bss} \mathrm{HII}\left(50^{\circ} \mathrm{C}\right.$ digestion) showed complete partial digestion between 5 and $20 \mathrm{~min}$. These optimized conditions enabled us to map several YAC clones with 5 different restriction enzymes, using only one lane of a pulsed-field gel per YAC and restriction enzyme.

Our method allows the construction of restriction maps of YAC clones in a rapid, very reproducible and economical (in time and resources) way and will therefore be of use for rapid alignment of YAC clones into contigs.

\section{REFERENCES}

1.Albertsen, H., H. Abderrahim, H. Cann, J. Dausset and D. Cohen. 1990. Construction and characterisation of a yeast artificial chromosome library containing seven haploid genome equivalents. Proc. Natl. Acad. Sci. USA 87:4256-4260.

2.Bellanné-Chantelot, C., B. Lacroix, P. Ougen, A. Billault, S. Beaufils, S. Bertrand, I. Georges, F. Glibert, G. Gros, et al. 1992. Mapping the whole human genome by fingerprinting yeast artificial chromosomes. Cell 70:1059-1068.

3.Burke, D.T., G.F. Carle and M.V. Olson. 1987. Cloning of large segments of exogenous DNA into yeast by means of artificial chromo- 


\section{Benchmarks}

some vectors. Science 236:806-812.

4.Chu, G., D. Vollrath and W. Davis. 1986. Separation of large DNA molecules by contour clamped homogeneous electric fields. Science 243:1582-1585.

5.Del-Favero, J., M. Vauterin, G. Weyens, K. Edwards and M. Jacobs. 1994. Construction and characterisation of a yeast artificial chromosome library containing five haploid sugar beet (Beta vulgaris L.) genome equivalents. Theor. Appl. Genet. 88:449-453.

6.Dreyer, K. and H. Schulte-Holthausen. 1991. Casein is a potent enhancer for restriction enzyme activity. Nucleic Acids Res. 9:4295.

7.Freinberg, A. and B. Vogelstein. 1983. A technique for radioactive labeling DNA restriction endonuclease fragments to high specific activity. Anal. Biochem. 132:6-13.

8.Green, E.D. and M.V. Olson. 1990. Chromosomal origin of the cystic fibrosis gene in yeast artificial chromosomes: a model for human genome mapping. Science 250:94-99.

9.Hamvas, R.M., Z. Larin, N. Brockdorff, S. Rastan, H.R. Lehrach, F.L. Chartier and S.D. Brown. 1993. YAC clone contigs surrounding the $\mathrm{Zfx}$ and Pola loci on the mouse $\mathrm{X}$ chromosome. Genomics 17:52-58.

10.Hamvas, R.M., F. Francis, R.D. Cox, D.
Nizetic, M.E. Goldsworth, S.D. Brown and H.R. Lehrach. 1994. Rapid restriction analysis of YAC clones. Nucleic Acids Res. 22:1318-1319.

This work was supported by Instituut voor aanmoediging van het Wetenschappelijk Onderzoek in Nijverheid en Landbouw (Agreement 5393 A), by a Ph.D. research fellowship appointed to Jurgen DelFavero. Address correspondence to Jurgen Del-Favero, Department of Biochemistry, Born-Bunge Foundation, University of Antwerp, Universiteitsplein 1, B-2610 Antwerpen, Belgium.

Received 9 August 1995; accepted 7 February 1996.

\section{Jurgen Del-Favero and Michel Jacobs \\ Institute for Molecular Biology \\ Sint-Genesius-Rode, Belgium}

\section{ADDENDUM}

The author of a recent BioTechniques article, "Plasmid Ligation Using a Sacrificial Insert", 19:351, 1995, has revised the acknowledgments as follows:

C.J.B. was supported in part by an NIH Biotechnology Training Grant (GM8412). Additional support for this research was obtained from an Arnold and Mabel Beckman Foundation Young Investigator Award and a Grant-In-Aid from the California Affiliate of the American Heart Association (94-270) to John H. Griffin. Address correspondence to Christopher J. Buntel, John H. Griffin Laboratory, Department of Chemistry, Stanford University, Stanford, CA 94305-5080, USA. Internet: benzene@leland.stanford.edu 